\title{
Strategic Information Moderated By Effectiveness Management Accounting Information Systems: Business Strategy Approach
}

\author{
Lilis Puspitawati \\ Accounting Departement Universitas Komputer Indonesia Bandung-Indonesia. \\ Email Address: \\ lilis.puspitawati@email.unikom.ac.id
}

\begin{abstract}
The industrial revolution 4.0 increases business competition and the increasing need for accounting information for strategic decision making. Accounting information is financial information needed by managers to predict and determine the company's strategic policies in the future, however, the current condition of many companies has not been able to produce quality accounting information which has an impact on the production of inappropriate financial policies. This study aims to determine how much the business strategy affects the effectiveness of the use of accounting software and how much the effectiveness of accounting software affects the quality of accounting information. The population in this study were 472 managers of state-owned companies and a total sample of 312 managers of BUMN which were determined by simple random sampling technique. Testing data using covariance-based structural equation modeling (SEM) with Lisrell software. The results of this study prove that State-Owned Enterprises in Indonesia effective application software affects quality accounting information, as well as the company's business strategy affects the effectiveness of accounting software.
\end{abstract}

Keywords: Quality of Accounting Information, Business Strategy, Accounting software and Management Accounting Information System.

\begin{abstract}
Abstrak: Revolusi industri 4.0 meningkatkan persaingan usaha dan meningkatnya kebutuhan informasi akuntansi untuk pengambilan keputusan strategis. Informasi akuntansi merupakan informasi bersifat finansial dibutuhkan oleh manajer untuk memprediksi dan menentukan kebijakan strategis perusahaan di masa depan, namun kondisi yang terjadi saat ini banyak perusahaan belum mampu menghasilkan informasi akuntansi yang berkualitas yang berdampak pada dihasilkannya kebijakan finansial yang tidak tepat. Penelitian ini bertujuan untuk mengetahui seberapa besar strategy bisnis berpengaruh terhadap efektifitas penggunaan software akuntansi dan seberapa besar efektifitas softwre akuntansi berpengaruh terhadap kualitas informasi akuntansi. Populasi dalam penelitian ini adalah 472 pengurus perusahaan BUMN dan jumlah sampel sebanyak 312 pengurus BUMN yang ditentukan dengan teknik simple random sampling. Pengujian data menggunakan model persamaan struktural berbasis kovarian (SEM) dengan software Lisrell. Hasil penelitian ini membuktikan bahwa Badan Usaha Milik Negara di Indonesia software aplikasi yang efektif berpengaruh terhadap Informasi akuntansi yang berkualitas, serta strategy bisnis perusahaan berpengaruh terhadap efektifitas software akuntansi.
\end{abstract}


Kata Kunci: Kualitas Informasi Akuntansi, Strategi Bisnis, software akuntansi, Sistem Informasi Akuntansi Manajemen.

\section{INTRODUCTION}

Organizations need strategic information to achieve competitive advantage, which used to plan the objectives of the organization and to assess whether those objectives are being achieved in practice. Strategic information generated from the Strategic Information Systems (SIS) are information systems that utilize Business Strategies policies in generating strategic information to help managers create new strategic options. Management Accounting Information System (MAIS) is one type of Strategic Information Systems that can be used manager in several company to identify and to understand the strategic issues as the requirements for changes in Business Strategies to survive in a competitive environment. Managers must obtain, interpret, and control the flow of information from the company environment so that they are not surprised by these threats and even prepares for a wide range of possibilities that will happen to deal with the strategic issues. In a competitive business environment, managers must take information from internal and external environment. Business Strategies of an organization provides the information from internal and external environment of their organization to the managers who need it (Heidmann, 2008).

Business Strategies can lead MAIS to generate Management Accounting Information which is needed by managers at various levels of the organization in achieving competitive advantage. The increase of company service to improve customer satisfaction by providing flexibility to the customers and business partners to be able to access information on products and services of the company directly through the web browsers that are provided by the company will reflect influential Business Strategies to the Efectiveness of MAIS (Mc. Leod et al., 2007).

Business Strategies adopts generic competitive strategies (Porter, 1985) which consist of cost leadership, differentiation and focus. Furthermore, the measurement model of Business Strategies is re-developed. (Palepu et al., 2000) measure through the points of view, namely diversification, cost leadership and differentiation. Similar to (Romey and Steinbart, 2006) measure Business Strategies through the points of view, namely product differentiation and low-cost strategy.

Managers have an important role to be able to ensure changes in the business environment which are followed by the changes in MAIS that are used by the company (Susanto, 2017). MAIS plays an important role in many decisions that managers make and it can provide relevant data for guiding line of strategic decisions on personnel (Hoque, 2004).

MAIS is a sub-system of accounting information which performs the activities of recording, processing and communication of financial information in accordance with the selection of user to internal/manager of a company (Bockholdt, 1999). MAIS is an Information Systems (IS) that conducts the activities to collect, to classify, to summarize and to report the information that helps employees within an organization to make the performance process of decision-making, planning, controlling and measuring (Drury, 2011). 
Efectiveness of IS is a condition of users' satisfaction with IS or the perception of the system users about the desired information. It can be expressed as the availability of appropriate information with the desired one by many users (Nicolau, 2000). The success of IS investments is characterized by generating valuable information and providing user satisfaction that affects individual and organizational performance. User satisfaction and system usage has been widely used by many studies to measure the effectiveness of IS.

Furthermore, (Seddon, 1997) develops a model using five (5) dimensions, namely system quality, information quality, user satisfaction and use of information systems. Similar to the previous opinion, Efectiveness of MAIS can be measured through system used and provide satisfaction to the user (Puspitawati, 2016). MAIS isused to make better decisions to improve the implementation of business processes and services to consumers within an organization (Laudon, 2014). Improving customer satisfaction that is reflected in the availability of rapid response to customer demand, by ensuring the delivery of 100 percent on time and by reducing the time that is needed to develop and to carry new products to market by identifying and by reporting time that is spent on the activities that have added value and those that do not have added value are the steps of MAIS to guide the organization to succeed in acompetitive business environment (Drury, 2011).

MAIS and IS that provides Management Accounting Information are required to satisfy specific management objectives. Furthermore (Hansen and Mowen, 2007) states that, Management Accounting Information is produced by MAIS which is focused for internal users such as managers, executives and employees in decision making. It is used in all phases of management. The top level manager uses it to determine the objectives of the organization, to compile policies and strategies which are needed to achieve those goals. The intermediate level management uses it to perform the activities of planning, organizing, putting, directing and controlling unit sales and production so that the Business Strategies of a company can be realized well. The bottom level management uses it to conduct the election activities which are most effective and efficient in carrying out the task of mid-level management as well as evaluating the results (Hansen et al., 2009).

This research is based on the phenomenon that there is a poor quality of accounting management information and can not be used in decision making process at some State Owned Enterprises (SOEs) in Indonesia. The impacts of this phenomenon are that companies can not compete with competitors because the selling price is too high and the products/ services do not meet customer satisfaction.

Based on the Introduction described earlier, this study aims to confirm the conceptual model designed to solve the problem of not qualified Management Accounting Information on SOEs in Indonesia, as well as to find out how Business Strategies policy is accommodated in Efectiveness of MAIS application and how it impacts on Qualtiy of Management Accounting Information in SOEs in Indonesia.

\section{THEORETICAL REVIEW}

Strategic Management Accounting. (Hoque, 2004) states strategic management accounting is a component of management accounting which is an activity to identify collecting, selecting and analyzing accounting data to assist the management team to make strategic decisions and to assess organizational effectiveness. Activity Based Management, Activity Based Costing, Total quality Management, Just In Time and Customer Profitability 
Analysis are several techniques that can be used. According to (Chong and Chong, 1997), Activity Based Management is an integrated approach in which the focus of management attention on an activity that is to improve the customer and the profit of company, then $\mathrm{ABC}$ technique does recording and reporting techniques cost in ABM.

TQM is used to make continuous improvements to products or services that are developed by the company to achieve optimal competitiveness. TQM has the philosophy to work diligently at a high level of responsibility without defective products. Then, (Hoque, 2004) states that JIT is used to make the products or services of company reach to the customer on time. It is used, subsequently, the technique of Customer Profitability Analysis to determine the group of potential customers that can generate profits for the company. To analyze the value chain by providing after sales service to improve customer satisfaction is the next step taken.

Bussiness Strategy. In achieving competitive advantage, business strategy implementation can assist companies to realize cost leadership strategies, differences and focus. (Kourdi, 2009), states the plans, various alternative solutions and decisions that are used to guide a company in generating greater profits and achieving the success of it is business strategy. Furthermore, (Campbell et al., 2002) states it is the basis for determining the company objectives and long-term goals, for implementing the real action and sharing the resources which are required to implement the various objectives that must be accomplished. Then, states it is the way of companies to position in the environment to achieve a competitive advantage.

In this study, the measurement of business strategy adopts generic competitive strategies which are proposed by (Porter, 1985) it consists of cost leadership, differentiation and focus. Furthermore, the measurement model of business strategy is re-developed by (Palepu et al., 2000) measure through the points of view, namely diversification, cost leadership and differentiation. Similar to (Romney and Steinbart, 2012) measure business strategy through the points of view, namely product differentiation and low-cost strategy.

Effectiveness of Management Accounting Information Systems. Effectiveness of Information Systems as it is stated by (Nicolau, 2000) is a condition of users satisfaction on information systems or the perception of the system users to the desired information. It can be expressed as the availability of appropriate information (right) with the desired one by many users. Further (De Lone et al., 2003) states it is how investments in information systems that are conducted by management can produce valuable output as it is measured by the information system which is used, can provide satisfaction to the user and can give influence to individuals and organizations.

(De Lone et al., 1992) has widely used the basis of a number of studies to assess the effectiveness of information systems implementation. The dimensions that are used to measure them are: system quality, information quality, service quality, system use, user satisfaction, and net benefits. Furthermore develops a model of it by using five (5) dimensions: system quality, information quality perception of the use level, user satisfaction and use of information systems.

Technology Acceptance Model (TAM) as it is proposed by (Davis et al., 2009) and (Venkantesh et al., 2003) use Perceived usefulness and Perceived Ease of Use as the indicator of the dimension of the system use. Then, (Duggan and Reichgelt, 2006) measures 
the indicators of system use (system use) are Ease of use, usefulness and Goodness in use. Similarly (Barrier, 2002) states for measuring dimensions of the system use (system use) as the indicators are: Easy in using (ease of use), easy to learn (ease of learning), Flexible in using (flexibility in use), Security (security).

Furthermore (Stair and Reynold, 2012), states the user satisfaction of information system depends on the quality of systems and information that can provide values/benefits to its users. says user satisfaction is the system provides information that correct and timely enough to satisfy the needs of user. (Puspitawati, 2016) in her research using the concept of user satisfaction and the use of the system in measuring the effectiveness of accounting information systems, and then information system through: (1) integration, (2) accessibility and (3) flexibility. Similarly, (Heidmann, 2008) uses four characteristics of quality information to gauge user satisfaction (user satisfaction), namely: integration, flexibility, accessibility, formalization and media richness.

Business strategy for the effectiveness of implementing information systems. Business strategy present in all business units and needed by the organization in facing business competition to achieve a competitive advantage with its competitors (Hoque, 2004). Business strategy through specific industries in the right market segmentation is an important factor to increase the position of competitive advantage in an organization (Wheelen et al., 2015).

Business strategy plays an important role in increasing the effectiveness of the use of information systems in the organization's business units. business strategy encourages information systems to produce information in accordance with the needs of managers at various levels of the organization, for example in the marketing unit, marketing managers can improve marketing services to increase customer satisfaction by providing flexibility to customers and business partners to be able to access product and service information company directly through a web browser provided by the company (Mc. Leod and Schell 2007).

To excel in business competition in a competitive environment is the goal of the organization. This condition requires managers to understand and identify strategic issues in order to be able to face various changes and survive in a competitive environment. Organizations must obtain, interpret and control information from the internal and external environment of the organization that managers need in identifying, managing and mitigating risks that arise in the organization. The use of business strategies in an organization encourages information systems to be able to provide information from the external and internal environment of the organization for managers throughout the organization's business units (Heidmann, 2008).

The research that has been conducted by (Chong and Chong, 1997), (Gill, 2004), (Reza et al., 2015), and (Xiaoying et al., 2008), has proved that business strategy is applied to an organization influence the effectiveness of management accounting information systems in fulfilling organizational goals to generate management accounting information which is used in strategic decision of making process.

Successful implementation of information systems to produce quality information. One of The information systems needed to provide accounting information for specific uses by managers is a management accounting information system (Hansen and Mowen 2007). 
Management accounting information system is a formal system that provides information to managers, and information systems are an integral part of information systems (Heidmann, 2008).

The successful application of an accounting information system in an organization affects the quality of accounting information produced by managers in an organization (Laudon, 2014). In line with various research results, it shows that the qualitative characteristics related to the production of information have an impact on the effectiveness of the use of information systems (Heidmann, 2008). Based on these various statements, it can be concluded that the quality of information is greatly influenced by the quality of the information system used by an organization.

These statements have been successfully proven by previous research conducted by (Chitmun and Ussahawanitchakit, 2011), (Sangsawang and Ussahawanitchakit, 2013), (Susanto, 2017) and (Puspitawati and Susanto, 2018). Based on the theory and previous research, furthermore developed the Conceptual framework of the research can be described as follows:

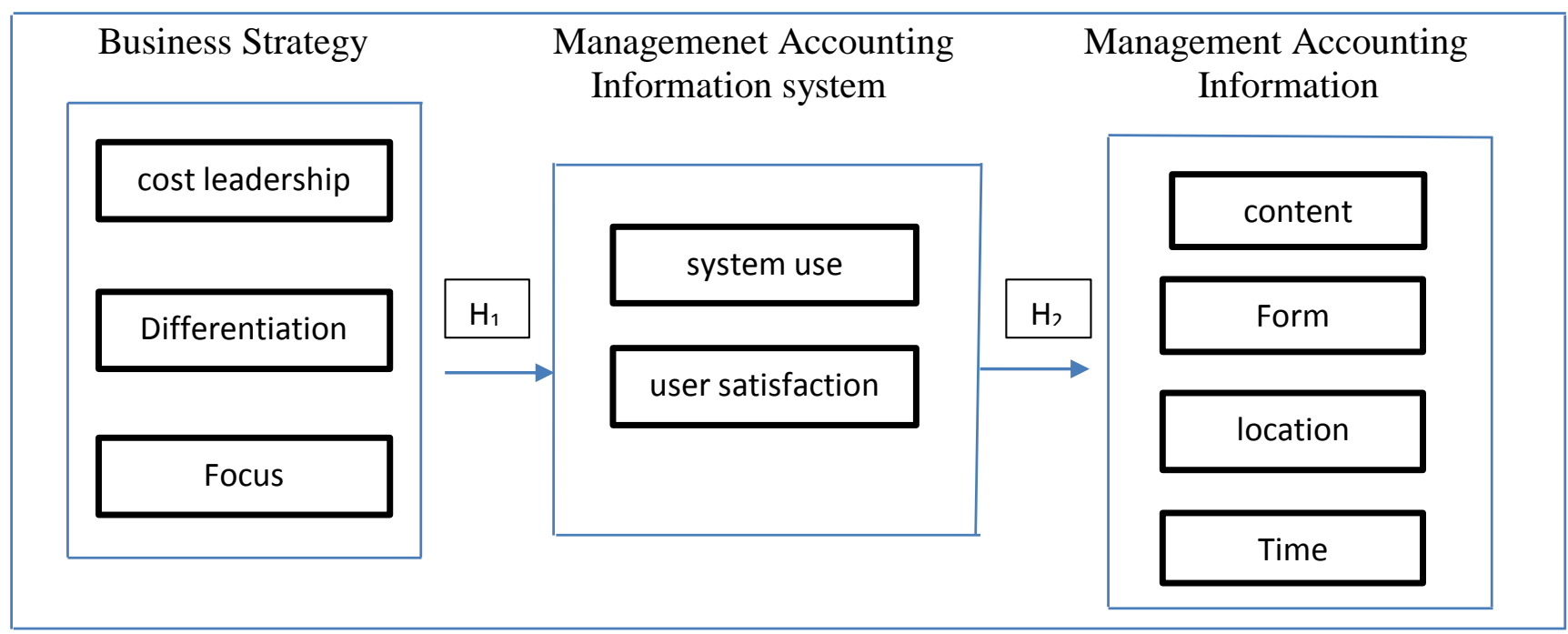

Figure 1. Research Model

Based on the literature review and the framework that have been previously stated, the hypothesis to be tested in this study is:

Hypothesis 1: Business Strategy affect The Effectiveness of Management Accounting Information Systems.

Hypothesis 2: Effectiveness of Management Accounting Information Systems affect The Management Accounting Information Systems.

\section{METHODS}

This study uses primary data which is respondent's statement related to the variables studied. The tool used to collect primary data is a questionnaire which is sent to respondents 
by direct mail, letter (mail survey) or by electronic mail (e-mail).The data collection was conducted for 3 months, from September to November 2019.

The research questionnaires will be tested using the test for validity, the test for reliability and the test for relevance. Validity test is used to determine the suitability of the measurement used in measuring the variables studied (Wijayanto, 2008). Reliability is the level of consistency of a result of a measurement. (Bollen and Currant, 2006) states that in reliability test a test is a reliable tool if it gives consistent results. While the relevance test conducted to determine the contribution of formative indicators to the construct testing the questionnaire using Lisrell software at the stage of suitability model matching model (Hair et al., 2014). The population in this study is the management accounting unit at 118 SOEs in Indonesia. The observation unit in this study is the financial accounting manager, management accounting manager and sales/marketing manager or representative staff. These managers or staff act as MAIS users to make decisions.

The data will be tested using Covarian Base - Structural Equation Model (SEM) analysis with Lisrell software. According to (Schumacer and Lomax, 2010) the recommended sample size for Maximum Likehood estimation using 5 (five) or less than 5 (five) minimum recommended quantities is between $100-150 .{ }^{25}$ States that it has been agreed that 100-150 subjects are a satisfactory minimum sample size for using structural equation models. Based on the statement, the sample size in this research is determined to total 100 SOEs. The sample size in the study is based on simple random sampling technique. This study uses descriptive and verificative methods.

Statistical Analysis- data analysis was conducted using Covarian Base-SEM with Lisrell Sofware and the steps are outlinedas follows:

Model specification. The initial model of structural equations is formulated based on previous research and relevant theories. The complete structural model can be seen in the chart below:

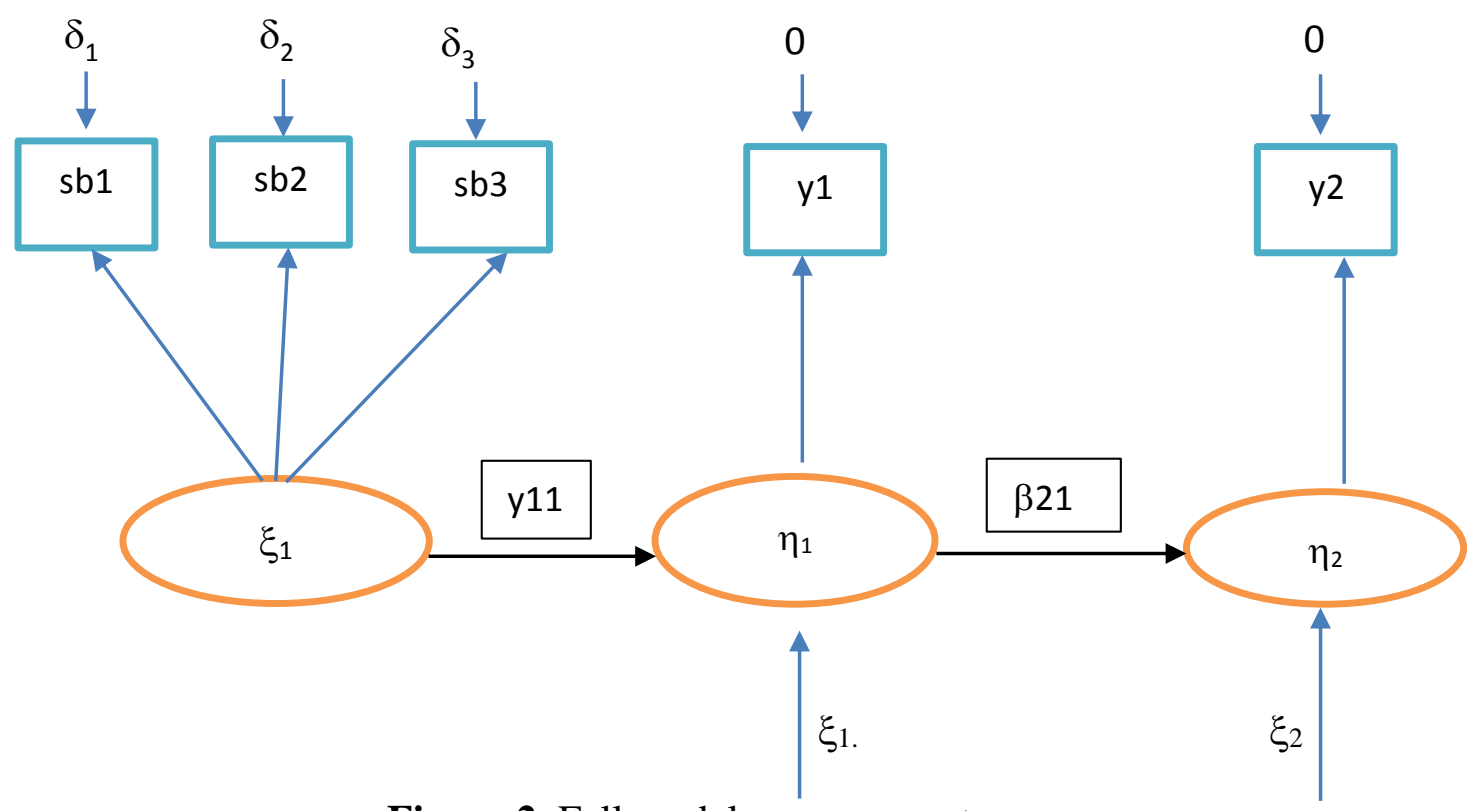

Figure 2. Full model measurement 


\section{Description:}

$\begin{array}{ll}\xi_{1} & : \text { Business Strategies } \\ \eta_{1} & : \text { Effectiveness of MAIS } \\ \eta_{2} & : \text { Quality of MAI } \\ \mathrm{Sb}_{1} & : \text { Cost Leadership } \\ \mathrm{Sb}_{2} & : \text { Differentiation } \\ \mathrm{Sb}_{3} & : \text { Focus }\end{array}$

Model identification. This stage involves a problem model that leads to the question of whether the model has enough information to obtain a unique solution to the parameters estimated in the model. A simple parameter is identified by calculating the degree of freedom.

Model estimation. Estimate to obtain values from the parameters present in the model. (Bollen and Currant, 2006) states that maximum likelihood estimator (MLE) is the most popular estimation method used in SEM.

fit model test. Model evaluation aims to evaluate the model as a whole, whether the model has a good fit or not. According to (Hair et al., 2014) the level of model fit can be done with the overall fit model, measurement fit model and structural fit model.

Model Respesification. Model Respesificationis conducted if the initial model proposed does not match against the existing empirical data. Model Modification can be made and retested by using the same data.

\section{RESULTS}

Business Strategies measured by using three dimensions namely cost leadership, differentation and focus. The dimensions will be described into 6 (six) point statements that are presented in the research questionnaire. The summary of the average score of statements from respondent on three dimensions of the Business Strategies at the SOEs in Indonesia is presented in table 1, as follows:

Table 1. Summary of mean of Business Strategy score

\begin{tabular}{l|c|c|c|c|c}
\hline Variable/ Dimension & Min & Max & Mean & $\begin{array}{l}\text { Standard } \\
\text { Deviation }\end{array}$ & Category \\
\hline Business Strategy (BS) & 1,00 & 4,64 & 2,00 & 1,01 & Poor \\
\hline Cost Leadership & 1,00 & 5,00 & 2,00 & 1,06 & Poor \\
\hline Differentiation & 1,00 & 4,67 & 2,02 & 1,02 & Poor \\
\hline Focus & 1,00 & 4,42 & 2,00 & 1,03 & Poor \\
\hline
\end{tabular}

Source: Results of data processing

The results of the study illustrate the condition of business strategy policy has not been applied to MAIS application that is used in SOEs in Indonesia, It means that MAIS applications used have not provided features that can be used in support of cost leadership, differentiation, and focus strategies.

Efectiveness of MAIS is formed through two (2) dimensions, namely system usage and user satisfaction. The following table presents the recapitulation of the average score to respondents' responses for each dimension on the Efectiveness of MAIS: 
Table 2. Summary of descriptive analysis Efectiveness of Management Accounting Information Systems

\begin{tabular}{l|c|c|c|c|c}
\hline \multicolumn{1}{c|}{ Dimension } & Min & Max & Mean & $\begin{array}{c}\text { Standard } \\
\text { Deviation }\end{array}$ & Category \\
\hline EMAIS & 2,40 & 4,90 & 3,78 & 0,59 & High \\
\hline System Usage & 2,43 & 5,00 & 3,86 & 0,55 & High \\
\hline User Satisfaction & 1,97 & 5,00 & 3,72 & 0,59 & High \\
\hline
\end{tabular}

Sources: the results of data processing

The table describes the application of MAIS application in SOEs in Indonesia has been included in good category, has been effectively used and has given satisfaction to its users. MAIS is able to process data accurately and integratedly, easy to use, secure, reliable, efficient to use and produce accurate and timely information.

Structural Equation Model Evaluation- Based on the test resultsusing Lisrell software, the degree of freedom (df) value in the SEM model are 11 (data in tabel 3), so it can be concluded that the model can be identified and included in the over identified category. A summary of the results on the overall of fit model evaluation will be presented in Table 3 as follows:

Table 3. Summary of the result on overall of fit model evaluation.

\begin{tabular}{l|c|c|c}
\hline \multicolumn{1}{c|}{ Goodness of Fit Index } & Cut-off & Result & Model ctiteria \\
\hline Chi-Square & $\mathrm{df}=11 ;$ & 11.4772 & Marginal \\
\hline Probability (sig) & $\geq 0,05$ & 0.4042 & Fit \\
\hline $\begin{array}{l}\text { Root Mean Square Error of Approximation } \\
\text { (RMSEA) }\end{array}$ & $<0,08$ & 0.02507 & Close Fit \\
\hline Root Mean Square Residual (RMR) & $<0,1$ & 0.07927 & Fit \\
\hline Goodness-of-Fit-Index (GFI) & 0 s.d 1 & 0.9546 & Good Fit . \\
\hline
\end{tabular}

Sources: SEM Listrell data processing

Based on the results of fit model using Chi square, RMSEA, RMR, and GFI, it can be concluded that the model which is proposed in this study in overall has goodness of fit measure and indicates acceptable model.

Reliability testing aims to test the consistency of research instruments in measuring a concept. According to ${ }^{4}$ to measure the reliability on a reflective indicator can use the value of $R^{2}$. An indicator is reliable if the value of $R^{2}$ is not less than 0.5. The summary of Individual Reliability test results are presented in Table 4 as follows: 
Table 4. Summary of the results of the reliability testing on business strategy variables

\begin{tabular}{l|l|c|c|c|c|c|c}
\hline \multicolumn{1}{c|}{ Latent } & Indicator & $\begin{array}{c}\text { Standardize } \\
\text { Estimated }\end{array}$ & error & $\begin{array}{c}\mathbf{Z} \\
\text { value }\end{array}$ & $\begin{array}{c}\mathbf{P} \\
\text { Value }\end{array}$ & $\mathbf{R}^{2}$ & Reliablity \\
\hline \multirow{2}{*}{ Cost Leadership } & BS1 & 0,947 & t.t. & t.t. & t.t. & 0,896 & very reliable \\
\cline { 2 - 8 } & BS2 & 0,985 & 0,050 & 20,647 & 0,000 & 0,969 & very reliable \\
\hline \multirow{2}{*}{ Differentation } & BS3 & 0,954 & t.t. & t.t. & t.t. & 0,910 & very reliable \\
\cline { 2 - 8 } & BS4 & 0,910 & 0,066 & 14,380 & 0,000 & 0,827 & very reliable \\
\hline \multirow{2}{*}{ Focus } & BS5 & 0,930 & t.t. & t.t. & t.t. & 0,864 & very reliable \\
\cline { 2 - 8 } & BS6 & 0,976 & 0,061 & 17,258 & 0,000 & 0,952 & very reliable \\
\hline
\end{tabular}

Sources: SEM Listrell data processing.

Description:

BS1: Lowest operating cost

BS2: Products and services with the lowest selling price

BS3: Various products and Services

BS4: Unique Products and Services

BS5: Focus on cost

BS6: Focus on Differentiation

The results of testing reliablity in table 4 shows that all indicators have value of $\mathrm{R}^{2}$ more than 0.5 which means that they have a very good level of reliability and can be interpreted that the indicators used have been consistently used to measure variable business strategy. Validity test aims to measure the quality of the instrument (questionnaire) used and indicates the level of validity of an instrument (questionnaire). Furthermore, (Hair et al., 2014) argue that the criterion of an indicator having a good convergence validity isif the indicator has a Variance Extract value greater than 0.5. Then, the standard of an indicator has a good internal consistencyif the Composite Reliability is above 0.7. The summary of the Variance Extract and Composite Reliability calculation is presented in Table 5 as follows :

Table 5. The Summary of the Variance Extract and Composite Reliability

\begin{tabular}{c|c|c|c|c|c|c}
\hline \multirow{2}{*}{ Latent } & Observed & Estimated default & 1-Estimated default & $\mathbf{R}^{\mathbf{2}}$ & VE & CR \\
\hline \multirow{2}{*}{ CL } & BS1 & 0,947 & 0,104 & 0,896 & 0,933 & 0,965 \\
\cline { 2 - 7 } & BS2 & 0,985 & 0,031 & 0,969 & & \\
\hline \multirow{2}{*}{ DIF } & BS3 & 0,954 & 0,090 & 0,910 & 0,868 & 0,930 \\
\cline { 2 - 7 } & BS4 & 0,910 & 0,173 & 0,827 & & \\
\hline \multirow{2}{*}{ FOS } & BS5 & 0,930 & 0,136 & 0,864 & 0,908 & 0,952 \\
\cline { 2 - 7 } & BS6 & 0,976 & 0,048 & 0,952 & & \\
\hline
\end{tabular}

Sources: SEM Listrell data processing

\section{Description:}

VE : Variance Extract

CR : Composite reliablity

Based on table 5, it can be concluded that all dimensions have VE value greater than 0.5 , which means that all dimensions have indicators with good convergence validity. Then, the table shows that all the dimensions have value of $C R>0.7$, which means that the 
indicators in each dimension has a good internal consistency. Based on the results of CR and VE testing it can be interpreted that all questionnaires used to measure the dimensions of business strategy have been qualified and havegood level of validity.

Furthermore the Efectiveness of MAIS is formed through 2 (two) formative dimensions,namely: system usage and user satisfaction. Summary result of the measurement of formative dimensions on Efectiveness of MAIS is presented in table 6, as follows:

Table 6. Summary Result of Efectiveness of Management Accounting Information Systems

\begin{tabular}{l|l|r|r|r|r|r|l}
\hline \multicolumn{1}{c|}{ VARIABLE } & \multicolumn{1}{|c|}{ DIMENSION } & Weight & \multicolumn{1}{c|}{ Error } & z-value & p-value & sig & Relevance \\
\hline \multirow{2}{*}{ EMAIS } & System Usage & 0,544 & 0,026 & 20,951 & 0,000 & sig. & relevance \\
\cline { 2 - 8 } & User Satisfaction & 0,839 & 0,011 & 76,681 & 0,000 & sig. & relevance \\
\hline
\end{tabular}

Sources: SEM Listrell data processing

Table 6 , shows the dimensions have $\mathrm{p}_{\text {-values }}$ which is smaller than the significance level (0.05), so it can be expressed all dimensions provide significant and relevant contribution to measure Efectiveness of MAIS. The Quality of Management Accounting Information is formed through 4 (four) formative dimensions, namely: time, content, location and form. Summary result of the measurement of formative dimensions on the Quality of Management Accounting Information variable is presented in table 7, as follows:

Table 7. Summary result of the measurement of formative dimensions on the Quality of Management Accounting Information

\begin{tabular}{c|l|l|l|l|l|l|l}
\hline \multicolumn{1}{c|}{ Latent } & Dimension & Weight & Error & z-value & p-value & sig & Relevance \\
\hline \multirow{3}{*}{ Quality of MAI } & Time & 0,492 & 0,011 & 46,255 & 0,000 & sig. & Relevance \\
\cline { 2 - 8 } & Content & 0,482 & 0,013 & 37,488 & 0,000 & sig. & Relevance \\
\cline { 2 - 8 } & Location & 0,542 & 0,060 & 9,072 & 0,000 & sig. & Relevance \\
\cline { 2 - 8 } & Form & 0,482 & 0,013 & 37,488 & 0,000 & sig. & Relevance \\
\hline
\end{tabular}

Sources: SEM Listrell data processing.

Table 7, shows that all dimensions of the Quality of Management Accounting Information have $\mathrm{p}_{\text {-values }}$ which is smaller than the significance level $(0.05)$, so it can be stated that all dimensions providedhas good contribution in forming the Efectiveness of MAIS variable.

Estimated Parameter Results: The structural model in this study needs to be simplified because there is aconstraintthat there is a formative measurement model that can not be accommodated when using the second order model. The modeling is as follows: 


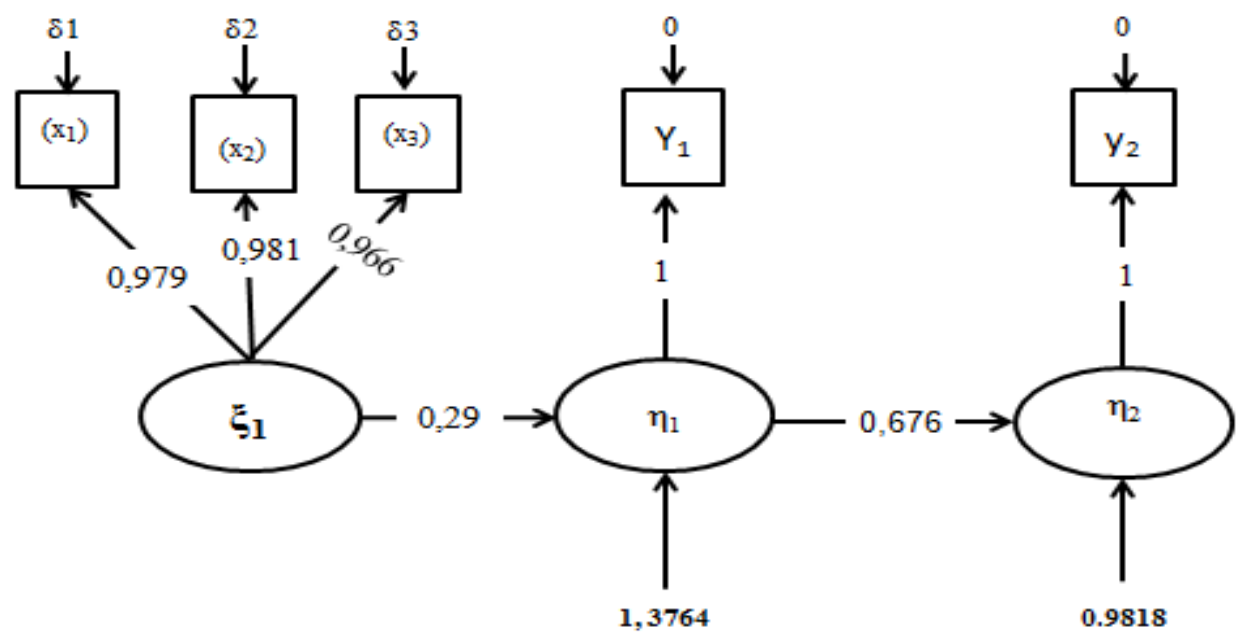

Figure 3. SEM Full Model result

Based on the model it can be stated that the effect of Business Strategies on Efectiveness of MAIS is 0.29. The test results show a weak influence. Then, the influence of Efectiveness MAIS on Quality of Management Accounting Information is 0.676 which means that Efectiveness of MAIS gives quite strong effect on Quality Management Accounting Information. The result of hypothesis testing of Business Strategies effect on Efectiveness of MAIS shows that $\mathrm{p}$-value is lower than 0.05, which means that Business Strategies has a significant effect on Efectiveness of MAIS IS in SOEs in Indonesia. Further more the result of hypothesis testing of Efectiveness of MAIS influence on Quality of Management Accounting Information shows that $p$-value is lower than 0.05 which means that Efectiveness of MAIS has significant effect on Quality of Management Accounting Information in SOEs in Indonesia.

\section{DISCUSSION}

This research has shown that SOEs in Indonesia has not been able to provide strategic information that helps senior managers in strategic decision making to achieve competitive advantage, because up to now Strategic Information Systems in SOEs has not been adequately applied in the company's main daily activities. This proves that there are malfunctions of decision support system aids in SOEs in Indonesia.

The results of this study illustrate that the application of MAIS in SOEs in Indonesia does not accommodate Business Strategies; therefore the features/menus available in the MAIS application can not provide strategic information such as Information on Competitors' costs, product/customer profitability, product pricing, the value of market share, effect of acquisitions/ mergers, capacity expansion, entry or exit decisions, shareholder's wealth, etc. that managers need in strategic decision making to achieve competitive advantage. Without strategic information, the company can not compete with its competitors.

The condition illustrated by the results of this study proves a phenomenon in the background of research that strategic information is not yet available adequately for SOEs in Indonesia and caused MAIS in Indonesian SOEs ineffective and produce information that 
is not eligible for strategic decision making. We proved that state-owned companies in Indonesia using MAIS applications that have accommodated business strategy play an important role in generating relevant information that helps executives more effectively and efficiently in strategic decision making.

Our results have confirmed the significant direct impact of business strategy and Effectiveness of MAIS on SOEs in Indonesia, and these findings are consistent with prior research. Research conducted by (Abernethy and Guthrie, 1994), examine the differences in MAIS design parameters in the companies that adopt different strategic priorities. Based on a sample of 49 general managers of business units, the findings have shown that the effectiveness of a business unit depends on the compatibility between the information system design and the company's strategic posture. More effective MAIS is found in the companies that focus on the strategy of developing/innovating sustainable products/markets (Prospectors) than in the companies that protect relatively narrow and stable product markets (defenders). The results of this study have important implications for management accountants involved in the design and implementation of MAIS, especially in companies that adopt more innovative strategic postures. In particular, this study proves that SB through the innovation dimensions has an effect on the implementation of MAIS

These study are consistent with (Chong and Chong, 1997) examines the role of MAIS design on the relationship between: strategic business unit (SBU) strategy, SBU performance and perceived environmental uncertainty (PEU) on SBU performance. The responses of $62 \mathrm{SBU}$ managers, drawn from a cross-section of manufacturing companies in Western Australia, analysed using a path analysis. The results suggest that SBU strategy and PEU are important antecedents of MAIS design, and that broad scope MAI is an important antecedent of SBU performance.

Results of research are also consistent with (Gilbert and Singger, 1998) this study examined Perceived environmental uncertainty (PEU) and Business Strategies on MAIS Quality. MAIS design was assessed through four characteristics of information are scope, timeliness, aggregation, and integration. Business Strategies was assessed through the three strategic areas are marketing, operations, and administration. PCU was assessed through management's perception of the degree of change and unpredictability in various market and technological dimensions facing the organization. This research proves that Business Strategies has significant effect on MAIS.

This result of study are aligned with (Gill, 2004), this study examines the effect of accounting information system design on the performance of organizations pursuing different strategic priorities. The alignment between sophisticated accounting information systems and organizational strategy is analyzed. Result of study on 112 CEOs in 218 hospitals in Spain proved that the satisfaction of MAIS used was influenced by Business Strategies. Similarly, (Xiaoying et al., 2008) this study measures the influence of Business Strategies, IS strategy, and IS strategic alignment to the performance of IS and business performance. theoretical model is tested using SEM, the result of research has proven Business Strategies significantly influence the performance of IS, the result of this research has proved IS strategic alignment have predicted a greater influence on business performance than Business Strategies or IS strategy.

These results are consistent with previous studies of (Volonino et al., 1991), examines the Business Strategies that influence the development of executive information systems (EIS) which is one form of SIS in a company. Based on the experiences of the organization, 
shows that developing an EIS should be based on Business Strategies objectives consisting of (1) identifying the organization's strategic business objectives (2) identifying business processes; (3) the priority of critical business processes; (4) identification of information needed to support business processes, (5) identification of information linkages between business processes and (6) making plans for the development, implementation, and evolution of modular EIS. This study proves Developing EIS applications based on Business Strategies has helped companies become market-oriented and able to survive in competitive advantage.

The empirical results of (Reza et al., 2015) also support the relationship between Business Strategies and MAIS, This study examines the relationships among competition, Business Strategies, MAIS and organizational performance. It follows a SEM to propose Conceptual model and that these changes enhance performance. Change in strategy concerned in the model as change in competition causes change in strategy, and this in turn results in the change in MAIS. The outcome of the (Bastian and Muslich, 2012), study also supports the link of relational Business Strategies to MAIS, The data processed by a Partial Least Square (PLS). The results of this study are PCU and Business Strategies significantly positively associated to non-financial performance measurement systems in MAIS, but the financial performance of the measurement system is not significantly associated.

This study is also related to previous research that examines the influence of EMAIS on QMAI in various types of industries. (Chitmunt and Ussahawanitchakit, 2011) conducts research in 158 companies engaged in the food industry in Thailand and shows that integrated MAIS affects the resulting Quality of MAI, and the outcomes of this study are aligned with (Rani and Kidane, 2012), conducted research on 30 printing companies in Ethiopia; the results of these studies also proved that MAIS affects the Quality of MAI. Then, research conducted by (Sangsawang and Ussahawanitchakit, 2013) at 113 IT and Telecommunication companies located in Thailand, generated empirical evidence that Quality of MAIS has an effect on generating MAI that managers can use in making decisions. Similary, (Wongsim and Gao, 2011) exploring the influence of Accounting Information Systems on the quality of Accounting Information Adoption in Thailand. The results of this study have provided empirical evidence that the quality of accounting information generated from Accounting Information Systems has been influential in decision making. These results are consistent with previous studies of (Al-Hiyari et al., 2013) have examined factors that Affect MAIS Implementation and Quality of MAI in Malaysia. The results of these studies also proved that effectiveness of the MAIS has effect on the Quality of MAI in malaysia. Futhermore, the research result of (Susanto and Meiryani, 2018) in Indonesia have succeeded in proving quality information influenced by the quality of the accounting information system.

This research has illustrated that SOEs as government-owned business organizations should have SIS to assist managers in strategic decision-making. SIS is needed by the company in providing strategic information that supports the company's competitive advantage. Important things that must be done by SOEs in improving the quality of strategic information at this time are: Firstly, State Management agencies should be well aware of their important role in carrying out strategic management activities in enterprise business processes. Therefore, there should be restrictions on decisions of political nature that directly affects enterprise development. The implementation of strategic management in SOEs in Indonesia can be done through the stages of strategic analysis, strategic choice, 
implementation of chosen strategies and review and control. These stages can be explained as follows:

1. Strategic analysis can be done by two ways, namely:

a. Performing Enviromental Scanning through SWOT analysis (Strength, Weakness, Opportunity and Threat); environmental scanning helps managers in knowing the best course of operations to have a good understanding of their operations as well as to implement key strategies for corporate success. In the SWOT analysis strengths and weaknesses can be analyzed based on information from internal company. Opportunities and Threats can be analyzed based on information from external companies.

b. Establishing the vision, mission, objectives to be achieved, strategy development and formation of various policies

2. Strategic Choice. There are two important things that managers must consider in choosing the right strategy for the company. The first thing to do is to choose the most appropriate option from the various options available, and the second is to evaluate the strategy we have chosen. Strategy selection should be based on the customer value creation through Value Chain Analysis. Companies can use cost leadership strategies, differentiation or focus strategies. Strategic policies will certainly be different in many companies; this should be tailored to the type of industry.

3. Implementation of Selected Strategies. The implementation is through the following stages:

a. the introduction of the market by using targeting and activity-based budgeting techniques.

b. creating products/services by using activity based costing and activity based management techniques.

c. building products/services based on the concept of total quality management (TQM).

d. launching products/services based on the concept of just in time (JIT) and customer profitability analysis (CPA)

e. after sales service, is an activity to maximize the fulfillment of customer satisfaction so that customer value can be improved.

4. Evaluate and control with Balance Scorecard implemented through four perspectives, that is financial perspective, customer, internal business and growth and learning.

Secondly, managers should provide great support and attention to MAIS development or restructuring. The development/ restructuring of this system will involve the development of specific organizational structures, policies, regulations, processes, operations and job assignments of each department. Adopting business strategies in MAIS applications is a long process; companies must develop flexible systems under any circumstances that can adapt to the development of the world economy. MAIS restructuring must provide menus or features that accommodate the current business strategy policy. the business strategy adopted in the MAIS Application provides strategic information useful to managers for decision making in determining the lowest selling price, determining products/services demanded by consumers and innovating products/services

Thirdly, SOEs in Indonesia must build adequate Database Management Systems (DBMS) to support the business lines associated with the company. In this way, the company will have BIG DATA containing important information from within and outside the company so that economic forecasting and competitor analysis activities are more 
reliable. It is recommended to consider using experienced outsource IT services to manage DMBS to ensure DBMS is properly managed.

Fourthly, SOEs in Indonesia must develop qualified human resources to support the implementation of SIS by having a road map to recruit, train, and improve their staff knowledge and skill in an intrinsic way. Human resource development must be in line with changes in science and technology and global economic conditions.

\section{CONCLUSION}

Based on the results of the research, the hypothesis is proved by assuming the findings that Business Strategies has a significant influence on Efectiveness of MAIS, and Efectiveness of MAIS has a significant influence on Quality of MAI in Indonesian SOEs In fact, this study shows that Business Strategies through Efectiveness of MAIS indirectly affects Quality of MAI. This study also proves that to improve the quality of MAI in the company, managers must design MAIS applications in accordance with business strategy policies.

This study discovers the empirical evidence that improving Quality of MAI is influenced by the MAIS that has adopted the company's Business Strategies policy that can be beneficial for managers in taking decisions to maintain the survival of the company. This study will help the researcher to uncover the critical areas of the MAIS application development in improving QMAI that many researchers were not able to explore. Thus a new theory on MAIS application development may have arrived.

Acknowledgement. We are indebted to the Ministry of Research,Technology and Higher Education of the Republic of Indonesia for research funding support fordissertation through Doctoral Dissertation Grant based on Decree on Research and Development Enhancement number 1/E/KPT/2018 dated January 32018.

\section{REFERENCES}

Abernethy, M.A and Guthrie, C.H. (1994). "An Empirical Assessment of the 'Fit' between Strategy \&management Information System Design.” Accounting \& Finance, Vol.34, No.2, Page.49-66.

Ahmad Al-Hiyari, Mohammed Hamood Hamood AL-Mashre , Nik Kamariah Nik Mat, Jamal Mohammedesmail alekam. (2013). "Factors That Affect Accounting Information System Implementation and Accounting Information Quality: A Survey in University Utara Malaysia." American Journal of Economics. 2013, 3(1): 27-31.

Barrier, T. (2002). Human Computer Interaction and Management. USA: IRM Press.

Bastian, Elvin, and Munawar Muslich. (2012). "Perceived Environment Uncertainty, Business Strategy, Performance Measurement Systems and Organizational Performance." Procedia - Social and Behavioral Sciences. Vol. 65 page 787 - 792.

Bockholdt, J. L. (1999). Acounting Information System. Fifth Edition. Singapore: Mc. GrawHill.

Bollen, Kenneth. A and Currant, Patrick. J. (2006). Latent Curve Models Structural Equation Perspective. Canada. Jhon Willey \& Sons.

Campbell; D Edgar; and G Stone House. (2002). Business Strategy: An Introduction. 
Second Edition. United Kingdom: Butterworth-Heinemann an Imprint of Elsevier Sciencez.

Chitmun, S and Ussahawanitchakit, P. (2011). "Management Accounting Systems Sophistication and Decision Making Performance." Journal of Academy of Business and Economics. Vol.11, No. 3.

Chong, V.K. and Chong, K.M. (1997). "Strategic Choices, Environmental Uncertainty and SBU Performance: A Note on the Intervening Role of Management Accounting Systems." Accounting and Business Research. Vol. 27, page 268-276.

Collin Drury. (2011). Management Accounting For Business Decision. 2nd Edition. United Kingdom: Thomson Learning.

Davis, Joshua M., William J. Kettinger and Dimitar G. Kurev. (2009). "When User Are It Expert to the Effects of Join IT Competence and Partnership on Satisfaction with Enterprise Level System Implementation." European Journal Of Information System. Vol. 18, Page.26-37.

De. Lone, William H and Ephraim R. McLean. (1992). "Information System Success: The Quest for The Dependent Variable." Information System Research. 3 (1) (March). Pp.60-94.

De. Lone, William H and Ephraim R. McLean. (2003). "Information Systems Success: TheQuest for the Dependent Variable." Information System Research The Instituteof Mangement Science. Page. 15.

Duggan, Evan. W and Han Reichgelt. (2006). Meassuring Information System Delivery Quality. Idea Group Publishing, USA.

Gilbert, Arthur H and Joseph F Singger. (1998). "An Analysis of The Relationship among Perceived Environmental Uncertainty and Business Strategy." Proceedings of the Academy of Information and Management Science.Vol 2. Number 2. Myrtle Beach.

Gill, David Narajo. (2004). "The Role of Sophisticated Accounting System in Strategy Management." The International Journal of Digital Accounting Research.

Hair, Joseph F., G. Thomas M. Hult., Christian M. Ringle., and Marko Sarstedt. (2014). A Primer on Partial Least Squares Structural Equation Modeling (PLS-SEM). USA: Sage Publications, inc.

Hansen, D. R. and Mowen, M. M. (2007). Managerial Accounting 8th Edition. USA: Thomson.

Hansen, D.R; Mowen, M.M \& Liming Guan. (2009). Cost Management Accounting \& Control Sixth Edition. USA: South-Western Cengage Learning.

Heidmann, Marcus. (2008). The Role Management Accounting System in Strategic Sensemaking. Deutcher Universitats Verlag, Germany.

Hoque, Zahirul. (2004). Strategic Management Accounting: Concept, Processes and Issues. Second Edition. USA: Spiro Press.

Kourdi, Jeremy. (2009). Business Strategy: A Guide to Taking Your Business Forward. Second Edition. London: Profile Books Ltd.

Laudon, Kenneth. C and Jane P. Laudon. (2014). Management Information System: Managing The Digital Firm. Thirteenth Edition. USA: South-Western Cengage Learning.

Mc. Leod, R and Schell, G. P. (2007). Management Information Systems. 10th edition. New Jersey: Pearson Education.

Nicolau, A.I. (2000). "A Contigency Model Perceived Effectiveness in Accounting 
Information Systems: Organizational Condition and Controll Effect.” International Jurnal Of Accounting Information System. 1(2).

Paul M. Healy, Palepu, Khrisna G, and Victory L. Bernard. (2000). Business Analysis \& Valuation. 2nd Edition. 2000. USA: South Western College Publishing.

Porter, Michale. E. (1985). Competitive Advantage: Creating and Sustaining Superior Performance. New York: The Free Press.

Puspitawati, Lilis. (2016). "The Analysis of Effectiveness Measurement In Accounting Information Systems Through Competence Factor Of Information System UserResearch on Higher Education in Bandung." IJABER, Vol. 14, No.2., pp.815-841. Serials Publications.

Puspitawati, Lilis, and Azhar Susanto. (2018). “The Influence of Business Strategy through the Management Accounting Information System to the Quality of Management Accounting Information Evidence in Indonesia." International Conference on Business, Economic, Social Science and Humanities (ICOBEST 2018) Atlantic P.

Rani, D. L. and Kidane, F. (2012). "Characteristics and Important Quality Factors of Management Accounting Information System." Radix International Journal of Banking, Finance and Accounting (RIJBFA) Volume 1.

Reza Ghasemi, Noor Azmi Mohamad, Meisam Karami, Norkhairul Hafiz Bajuri, Ezzatollah Asgharizade. (2015). "The Relationship among Strategy, Competition and Management Accounting Systems on Organizational Performance." European Online Journal of Natural and Social Science. www.european-science.com. Vol.4, No.3 pp. 565-581.

Romney, Marshall B and Steinbart, Paul John. (2006). Accounting Information Systems, Tenth Edition. USA: Pearson Education.

Romney, Marshall B and Steinbart, Paul John. (2012). Accounting Information Systems, Twelfth Edition. USA: Pearson Education.

Sangsawang and Ussahawanitchakit. (2013). "Best Managerial Accounting Information and Firm Performance: An Empirical Investigation of Information Technology \& Communication Bussiness In Thailand." Review of Business Research Vol. 13 Is.

Schumacer, E. Randall and Lomax, Richard. (2010). Beginner's Guide to Structural Equation Modeling. Third Edition. New York: Routledge-Taylor \& Francis Group.

Seddon, P.B. (1997). "Information System Research.” Vol. 8 No.

Stair, Ralph M and George Reynold. (2012). Fundamental of Information Systems. Sixth edition.USA: Cengage Learning.

Susanto, A and Meiryani. (2018). "The Quality of Accounting Information System and Its Impact on the Quality of Accounting Information: User Ability and Top Management Support." Journal of Engineering and Applied Sciences. 13 (2). Page 384-387. Medwell Journal.

Susanto, Azhar. (2017). "How the Quality of Accounting Information Systems Impact on Accounting Information Quality (Research on Higher Education in Bandung)." Journal of Engineering and Applied Sciences 12 (14) 3672-3677. Medwells Journal.

Venkatesh, V., Morris, M.G., Davis, G.B., and Davis, F.D. (2003). "User Acceptance of Information Technology: Toward a Unified View." MIS Quarterly. Vol.27, No.3, Page.425-478.

Volonino, Linda and Hugh, J Waston. (1991). "The Strategic Business Objectives Method for Guiding Executive Information Systems Development.” Journal of Management 
Information Systems Vol. 7.

Wheelen Thomas L, David Hunger, Alan N. Hoffman and Charles E Bamford. (2015).

Strategic Management and Business Policy: Globalization, Inovation and Sustainability. USA: Fourthteenth Edition.

Wijayanto, Setyo Hari. (2008). Structural Equation Modelling Dengan Sofware Lisrell 8.8: Konsep Dan Tutorial SEM. Yogyakarata: Graha Ilmu.

Wongsim, Manirath, and Jing Gao. (2011). "Exploring Information Quality in Accounting Information Systems Adoption." IBIMA Publishing Communications of the IBIMA. Vol. 2011 (2011), page 12.

Xiaoying, Dong; Liu Qianqian and Yin Dezhi. (2008). "Business Performance, Business Strategy and Information System: Strategic Aligment: And Empirical Study on Chinese Firm." Tsinghua S. 